\title{
Influence of Smoking Status and Body Mass Index on Serum Carcinoembryonic Antigen Concentration in Patients with Thoracic Diseases
}

\author{
Masaki Tomita1, Takanori Ayabe¹, Kazuyo Tsuchiya1, Kunihide Nakamura² \\ ${ }^{1}$ Department of Thoracic and Breast Surgery, Faculty of Medicine, University of Miyazaki, Miyazaki, Japan \\ ${ }^{2}$ Department of Cardiovascular Surgery, Faculty of Medicine, University of Miyazaki, Miyazaki, Japan \\ Email:mtomita@med.miyazaki-u.ac.jp
}

How to cite this paper: Tomita, M., Ayabe, T., Tsuchiya, K. and Nakamura, K. (2017) Influence of Smoking Status and Body Mass Index on Serum Carcinoembryonic Antigen Concentration in Patients with Thoracic Diseases. Surgical Science, 8, 279-286.

https://doi.org/10.4236/ss.2017.87030

Received: June 7, 2017

Accepted: July 7, 2017

Published: July 10, 2017

Copyright $\odot 2017$ by authors and Scientific Research Publishing Inc. This work is licensed under the Creative Commons Attribution International License (CC BY 4.0).

http://creativecommons.org/licenses/by/4.0/

(c) (i) Open Access

\begin{abstract}
BACKGROUND: Although the serum carcinoembryonic antigen (CEA) concentration is the well-known prognostic marker of non-small cell lung cancer (NSCLC), serum CEA concentration has been reported to be affected by smoking status and body mass index (BMI). There are no previous investigations that examined the relationship between BMI and serum CEA concentration in thoracic disease, including NSCLC. METHODS: Consecutive 384 NSCLC patients and 87 patients with benign thoracic disease were enrolled. The relationship between serum CEA concentration and smoking status and BMI in patients with benign thoracic benign disease and NSCLC was examined. RESULTS: In patients with benign thoracic disease, serum CEA concentration significantly increased with smoking status and Brinkman index. However, serum CEA concentration was not related with BMI. Serum CEA concentration of patients with NSCLC was significantly higher than those with benign disease. In NSCLC patients, the relationship between serum CEA concentration and smoking status was also found. A significant relationship between serum CEA concentration and smoking status was also found in patients with adenocarcinoma which is known to have weaker associations with smoking in carcinogenesis. On the other hand, we failed to find the relationship between serum CEA concentration and BMI in NSCLC patients. CONCLUSION: Serum CEA concentration may be affected by smoking status but not BMI in our Japanese patients with thoracic disease.
\end{abstract}

\section{Keywords}

CEA, Smoking Status, Body Mass Index, Benign Thoracic Disease, Non-Small Cell Lung Cancer 


\section{Introduction}

Carcinoembryonic antigen (CEA) is one of these serologic markers of malignant tumors, including non-small cell lung cancer (NSCLC). Previous investigations showed the prognostic significance of serum CEA concentration in NSCLC [1] [2] [3].

However, some variables affect the serum CEA concentration. Cigarette smoking is one of the well-known variables associated with increased CEA concentrations. Previous investigations showed that serum CEA level were significantly higher in cigarette smokers than in non-smokers [4] [5].

Furthermore, other previous investigations had also shown that higher body mass index (BMI) is associated with lower CEA concentration in colorectal cancer patients [6] [7] and healthy males [8] [9].

In patients with thoracic disease, Okada et al. [10] reported the effect of smoking status on serum CEA concentration in NSCLC. However, to our knowledge, there are no previous investigations that showed the effect of BMI on serum CEA concentration in patients with NSCLC. As the effect of BMI on serum CEA concentration in patients with thoracic diseases is uncertain, we hypothesized that the prognostic precision of the serum CEA concentration in NSCLC might be affected by smoking and BMI status. Therefore, we designed the present study that examined the relationship between serum CEA concentration in thoracic begin disease and NSCLC.

\section{Patients and Methods}

This retrospective study had institutional review board approval, and the need to obtain patient consent was waived. Consecutive NSCLC patients who examined preoperative serum CEA concentration and underwent surgery from 2008 to 2013 in our hospital were enrolled into the present retrospective study. Furthermore, patients with benign thoracic disease who also underwent surgery during same period were also enrolled. Among these patients with benign diseases, patients who were not examined preoperative serum CEA concentration and those with clinical history of malignant disease were excluded. The collected records of 384 consecutive NSCLC patients and 87 patients with benign thoracic disease were reviewed retrospectively. The lifetime consumption of cigarette smoke was assessed using the Brinkman index (BI), calculated by the numbers of cigarettes smoked per day multiplied by the smoking years [11]. Based on the BI, patients were subdivided into 3 groups: never smoker $(\mathrm{BI}=0)$, light to moderate smoker $(\mathrm{BI}=1-500)$ and heavy smoker $(\mathrm{BI}>500)$. The preoperative BMI was calculated as weight in kilograms divided by height in meters squared. According to the previous investigation [6], the following categories were used: lower range of normal weight $\left(\mathrm{BMI}<18.5 \mathrm{~kg} / \mathrm{m}^{2}\right)$, normal weight $(\mathrm{BMI}=18.5-24.0$ $\left.\mathrm{kg} / \mathrm{m}^{2}\right)$ and overweight $\left(B M I>24.0 \mathrm{~kg} / \mathrm{m}^{2}\right)$. The clinicopathologcal factors of patients were shown in Table 1 and Table 2.

We used Wilcoxon rank-sum tests to assess associations between serum CEA concentration and smoking status, Brinkman index and BMI, with p-values 
computed using the normal approximation. All statistical analyses were performed using JMP (SAS Institute Inc., Cary, NC, USA).

\section{Results}

The study included 87 patients with benign thoracic disease, including 6 benign lung tumors, 33 benign mediastinal tumors, 37 inflammatory lung diseases and 11 others (Table 1). In NSCLC patients, there were 296 adenocarcinomas and 88 other histologic types (Table 2).

The serum CEA concentration (mean \pm S.D.) in patients with benign disease was $2.82 \pm 52.67 \mathrm{ng} / \mathrm{ml}$, while patients with NSCLC was $97.38 \pm 27.60 \mathrm{ng} / \mathrm{ml}$ $(\mathrm{p}<0.001)$.

In patients with benign thoracic diseases, the serum CEA concentration (mean \pm S.D.) of patients with never smoker and current/former smoker were $2.720 \pm 3.287$ and $2.957 \pm 1.519 \mathrm{ng} / \mathrm{ml}$, respectively $(\mathrm{p}=0.016)$. Similarly, the serum CEA concentration (mean \pm S.D.) of $\mathrm{BI}=0, \mathrm{BI}=1-500$ and $\mathrm{BI}>500$ group were $2.720 \pm 3.287,2.361 \pm 1.014 \mathrm{l}$ and $3.521 \pm 1.719 \mathrm{ng} / \mathrm{ml}$, respectively. Although, we failed to find a statistical difference between $\mathrm{BI}=0$ and $\mathrm{BI}=1$ 500 groups $(p=0.408)$, the serum CEA concentration of $\mathrm{BI}>500$ group was significantly higher $(\mathrm{BI}=0$ vs. $\mathrm{BI}>500: \mathrm{p}=0.003, \mathrm{BI}=1-500$ vs. $\mathrm{BI}>500: \mathrm{p}=$ 0.018). On the other hand, the serum CEA concentration (mean \pm S.D.) of BMI $<18.5, \mathrm{BMI}=18.5-24.0$ and $\mathrm{BMI}>24.0$ groups were $2.229 \pm 1.370,2.651 \pm$ 1.736 and $3.307 \pm 4.092 \mathrm{ng} / \mathrm{ml}$, respectively (BMI > 24 vs. $18.5-24: \mathrm{p}=0.558$,

Table 1. Clinical characteristics of patients with benign thoracic disease.

\begin{tabular}{ccc}
\hline & & No. of patients \\
\hline Age & $\leq 65$ & 48 \\
Gender & $>65$ & 39 \\
& Male & 47 \\
Smoking status & Nemale & 40 \\
& Current/former & 50 \\
Brinkman index & 0 & 37 \\
& $1-500$ & 50 \\
Histology & $>500$ & 18 \\
& Benign lung tumor & 19 \\
& Benign mediastinal tumor & 6 \\
Inflammatory lung disease & 33 \\
CEA & Others & 37 \\
& Normal & 11 \\
BMI & High & 78 \\
& $<18.5$ & 9 \\
& $18.5-24$ & 7 \\
& $>24$ & 53 \\
& & 27 \\
\hline
\end{tabular}

CEA: carcinoembryonic antigen, BMI: body mass index. 
Table 2. Clinical characteristics of patents with non-small cell lung cancer.

\begin{tabular}{|c|c|c|}
\hline & & No. of patients \\
\hline \multirow[t]{2}{*}{ Age } & $\leq 65$ & 125 \\
\hline & $>65$ & 259 \\
\hline \multirow[t]{2}{*}{ Gender } & Male & 198 \\
\hline & Female & 186 \\
\hline \multirow[t]{2}{*}{ Smoking status } & Never & 172 \\
\hline & Current/Former & 212 \\
\hline \multirow[t]{3}{*}{ Brinkman index } & 0 & 172 \\
\hline & $1-500$ & 58 \\
\hline & $>500$ & 154 \\
\hline \multirow[t]{2}{*}{ Histology } & Adenocarcinoma & 296 \\
\hline & Others & 88 \\
\hline \multirow[t]{2}{*}{ pStage } & I & 296 \\
\hline & II-IV & 88 \\
\hline \multirow[t]{2}{*}{ pT status } & pT1 & 259 \\
\hline & pT2-3 & 125 \\
\hline \multirow[t]{2}{*}{$\mathrm{pN}$ status } & pNo & 326 \\
\hline & $\mathrm{pN} 1-2$ & 58 \\
\hline \multirow[t]{2}{*}{ CEA } & Normal & 282 \\
\hline & High & 102 \\
\hline \multirow[t]{3}{*}{ BMI } & $<18.5$ & 59 \\
\hline & $18.5-24$ & 219 \\
\hline & $>24$ & 106 \\
\hline
\end{tabular}

CEA: carcinoembryonic antigen, BMI: body mass index.

BMI $>24$ vs. $<18.5: \mathrm{p}=0.406, \mathrm{BMI}=18.5-24$ vs. $<18.5: \mathrm{p}=0.519)$. There are no significant differences of serum CEA concentration among BMI groups. Using box and whisker plot, we further determined the distribution of serum CEA concentration in each subgroup (Figure 1).

In patients with NSCLC, the serum CEA concentration (mean \pm S.D.) of patients with never smoker and current/former smoker were $5.085 \pm 13.320$ and $9.234 \pm 35.093 \mathrm{ng} / \mathrm{ml}$, respectively $(\mathrm{p}<0.001)$. Similarly, serum CEA concentration (mean \pm S.D.) of BI groups were $\mathrm{BI}=0: 5.086 \pm 13.320$, BI $=1-500$ : $7.071 \pm 15.002$ and $\mathrm{BI}>500: 10.049 \pm 40.150 \mathrm{ng} / \mathrm{ml}$, respectively $(\mathrm{BI}>500$ vs. $0: \mathrm{p}<0.001, \mathrm{BI}>500$ vs. $1-500: \mathrm{p}=0.0456$ and $\mathrm{BI}=1-500$ vs. $0: \mathrm{p}=0.187)$. There was also a trend towards an association between serum CEA concentration and $\mathrm{BI}$ but the difference between $\mathrm{BI}=0$ and $\mathrm{BI}=1-500$ group did not reach statistical significance. The serum CEA concentration (mean \pm S.D.) of $\mathrm{BMI}<18.5, \mathrm{BMI}=18.5-24.0$ and $\mathrm{BMI}>24.0$ groups were $6.314 \pm 62.886$, $5.842 \pm 12.110$ and $5.572 \pm 15.402 \mathrm{ng} / \mathrm{ml}$, respectively (BMI > 24 vs. $18.5-24$ : $\mathrm{p}=0.313$, BMI $>24$ vs. $<18.5: \mathrm{p}=0.058, \mathrm{BMI}=18.5-24$ vs. $<18.5: \mathrm{p}=0.172)$. We also failed to find the significant differences of serum CEA concentration among BMI groups in patients with NSCLC. Box and whisker plots summarise these distributions (Figure 2). 


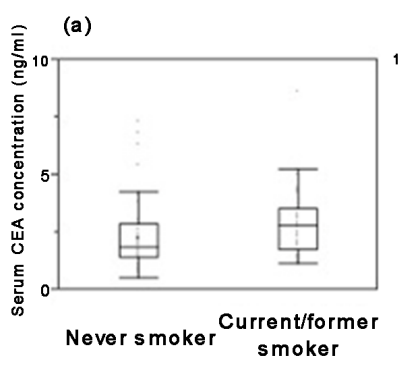

(b)

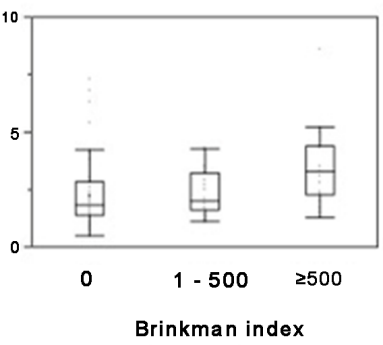

(c)

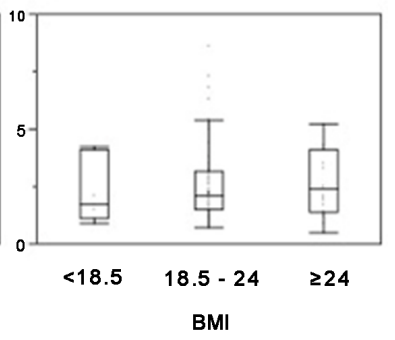

Figure 1. Box and whisker plot of patients with benign thoracic disease stratified by smoking status (a), BI (b) and BMI (c) demonstrating a difference in serum CEA concentration. BI: Brinkman index, BMI: body mass index, CEA: carcinoembryonic antigen.

In patients with adenocarcinoma, smoking is generally believed to play a less vital role in the cause or growth of the tumor compared with other types. Therefore, we also examined the relationship between serum CEA concentration and smoking status in patients with adenocarcinoma. The results of serum CEA concentration (mean \pm S.D.) in patients with adenocarcinoma were as follows: never smoker $(5.244 \pm 13.710 \mathrm{ng} / \mathrm{ml})$ vs. current/former smoker $(9.417 \pm$ $41.910 \mathrm{ng} / \mathrm{ml}): \mathrm{p}=0.005 ; \mathrm{BI}=0(5.244 \pm 13.710 \mathrm{ng} / \mathrm{ml})$ vs. $\mathrm{BI}>500(11.752 \pm$ $51.496 \mathrm{ng} / \mathrm{ml}): \mathrm{p}<0.001, \mathrm{BI}>500 \mathrm{vs.} \mathrm{BI}=1-500(5.096 \pm 9.549 \mathrm{ng} / \mathrm{ml}): \mathrm{p}=$ 0.013 and $\mathrm{BI}=1-500$ vs. $\mathrm{BI}=0: \mathrm{p}=0.784$.

\section{Discussion}

The present study is the first investigation that examined the relationship between BMI and serum CEA concentration in thoracic disease, including NSCLC. Our results showed a clear relationship between smoking status and serum CEA concentration in both benign thoracic diseases and NSCLC. To our knowledge, there are no previous investigations that denied an association between smoking and serum CEA concentration. Smoking is a major risk factor for lung cancer, especially in patients with squamous cell carcinoma. In patients with adenocarcinoma, smoking is generally believed to play a less vital role in the cause or growth of the tumor compared with other types. We also showed a clear relationship between smoking status and serum CEA concentration in patients with adenocarcinoma. Okada et al. [10] reported the effect of smoking status on interpretation of serum CEA concentration. They concluded that smoking status of patients should be taken into account when serum CEA concentrations are checked in NSCLC [10]. We should consider the possibility of loss of sensitivity and accuracy in the CEA test by smoking status.

BMI had been also reported to be one of the factors that affect serum CEA concentration, and serum CEA concentration significantly decreased with increasing BMI [6] [7] [8] [9]. Thus Park et al. [6] also concluded that the BMI status of patients should be taken into account during assessment of serum CEA during the surveillance of colorectal cancer. The reason for the relationship between BMI and serum CEA concentration has been considered to be the hemodilution effect of obesity patients [6] [7] [8] [9]. In other words, the larger 

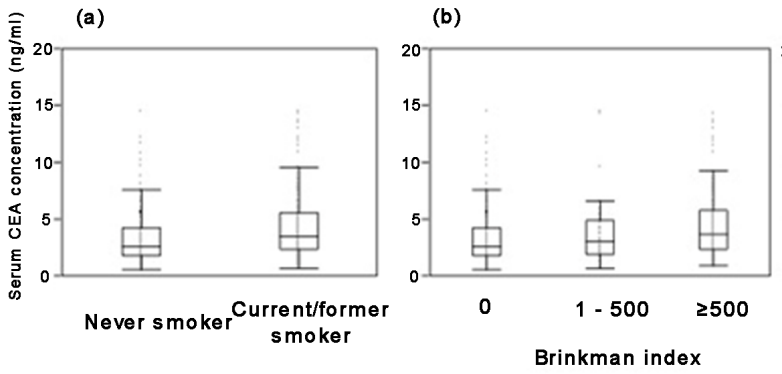

(c)

Figure 2. Box and whisker plot of patients with NSCLC stratified by smoking status (a), BI (b) and BMI (c) demonstrating a difference in serum CEA concentration. BI: Brinkman index, BMI: body mass index, CEA: carcinoembryonic antigen, NSCLC: non-small cell lung cancer.

vascular volume of obese patients might cause a dilution effect of CEA [8]. Furthermore, Li et al. [9] hypothesize other two possible reasons: First, an inflammatory state caused by obesity may result in greater leakage of CEA into the serum. Second, insulin resistance of obesity patients might contribute to the increased CEA. However, we failed to find this relationship in both benign thoracic diseases and NSCLC. The biological mechanism underlying this observation is not entirely clear although our findings are consistent with other previous investigations [12] [13]. One of possible reasons for this discrepancy is small number of extremely obese patients. The patients with BMI $>27.5$ is only $4.7 \%(22 / 471)$ of our study population. On the other hand, the ratio of patients with BMI > 27.5 in previous study population of Park et al. [7], Chang et al. [8] and Li et al. [9] were 6.9\% (224/3259), 8.6\% (752/8776) and 14.6\% (341/2359), respectively. Furthermore, our study population is Japanese patients. There are no previous investigations from Japan that showed the relationship between BMI and serum CEA concentration. Yoshiike et al. [14] reported that the standardized prevalence of obesity (BMI $>$ or $=30.0)$ in Japanese adults was quite low compared with the data in western populations. Taken together, because of small number of obese patients, there is a possibility that we might fail to find a dilution effect of CEA.

Conversely, other previous investigations [12] [13] reported that no association was found between serum CEA concentration and BMI in healthy cohorts. Our findings are consistent with these results [12] [13]. In addition to cigarette smoking, serum CEA concentration might be affected by several factors, including age, hypothyroidism and white blood cell count [9]. The reason for these conflicting findings [6] [7] [8] [9] [12] [13] might be explained by these factors. Further studies are warranted.

Our study's main limitations relate that all patients were surgery patients and the number of patients was small. Therefore, a large cohort study will be required to confirm our results.

\section{Conclusion}

In conclusion, serum CEA concentration may be affected by smoking status, but 
we failed to find a relationship between BMI and serum CEA concentration in both benign thoracic diseases and NSCLC.

\section{References}

[1] Okada, M., Nishio, W., Sakamoto, T., Uchino, K., Yuki, T., Nakagawa, A. and Tsubota, N. (2004) Prognostic Significance of Perioperative Serum Carcinoembryonic Antigen in Non-Small Cell Lung Cancer: Analysis of 1,000 Consecutive Resections for Clinical Stage I Disease. The Annals of Thoracic Surgery, 78, 216-221. https://doi.org/10.1016/j.athoracsur.2004.02.009

[2] Sawabata, N., Maeda, H., Yokota, S., Takeda, S., Koma, M., Tokunaga, T. and Ito, M. (2004) Postoperative Serum Carcinoembryonic Antigen Levels in Patients with Pathologic Stage IA Nonsmall Cell Lung Carcinoma: Subnormal Levels as an IndiCator of Favorable Prognosis. Cancer, 101, 803-809. https://doi.org/10.1002/cncr.20421

[3] Tomita, M., Matsuzaki, Y., Edagawa, M., Shimizu, T., Hara, M. and Onitsuka, T. (2004) Prognostic Significance of Preoperative Serum Carcinoembryonic Antigen Level in Lung Adenocarcinoma But Not Squamous Cell Carcinoma. Annals of Thoracic and Cardiovascular Surgery, 10, 76-80.

[4] Alexander, J.C., Silverman, N.A. and Chretien, P.B. (1976) Effect of Age and Cigarette Smoking on Carcinoembryonic Antigen Levels. Journal of the American Medical Association, 235, 1975-1979. https://doi.org/10.1001/jama.1976.03260440027017

[5] Stevens, D.P. and Mackay, I.R. (1973) Increased Carcinoembryonic Antigen in Heavy Cigarette Smokers. Lancet, 2, 1238-1239.

[6] Chen, W., Liu, Q., Tan, S.Y. and Jiang, Y.H. (2013) Association between Carcinoembryonic Antigen, Carbohydrate Antigen 19-9 and Body Mass Index in Colorectal Cancer Patients. Molecular and Clinical Oncology, 1, 879-886.

[7] Park, J.S., Choi, G.S., Jang, Y.S., Jun, S.H. and Kang, H. (2010) Influence of Obesity on the Serum Carcinoembryonic Antigen Value in Patients with Colorectal Cancer. Cancer Epidemiology, Biomarkers \& Prevention, 19, 2461-2468. https://doi.org/10.1158/1055-9965.EPI-10-0569

[8] Chang, I.H., Ahn, S.H., Han, J.H., Kim, T.H., Kim, Y.S. and Myung, S.C. (2009) The Clinical Significance in Healthy Men of the Association between Obesity Related Plasma Hemodilution and Tumor Marker Concentration. The Journal of Urology, 181, 567-572. https://doi.org/10.1016/j.juro.2008.10.030

[9] Li, F., Shen, Z., Lu, Y., Wang, L. and Song, W. (2014) How Much Does Body Mass Index Affect Serum Carcinoembryonic Antigen Concentration? Cancer Epidemiology, Biomarkers \& Prevention, 23, 555-560. https://doi.org/10.1158/1055-9965.EPI-13-0661

[10] Okada, M., Nishio, W., Sakamoto, T., Uchino, K., Yuki, T., Nakagawa, A. and Tsubota, N. (2004) Effect of Histologic Type and Smoking Status on Interpretation of Serum Carcinoembryonic Antigen Value in Non-Small Cell Lung Carcinoma. The Annals of Thoracic Surgery, 78, 1004-1009. https://doi.org/10.1016/j.athoracsur.2004.03.019

[11] Brinkman, G.L. and Coates Jr., E.O. (1963) The Effect of Bronchitis, Smoking, and Occupation on Ventilation. The American Review of Respiratory Disease, 87, 684-693.

[12] Herbeth, B. and Bagrel, A. (1980) A Study of Factors Influencing Plasma CEA Levels in an Unselected Population. Oncodevelopmental Biology and Medicine, 1, 
191-198.

[13] Lee, J.Y., Lee, H.K., Lee, D.C. and Lee, J.W. (2012) Serum Carcinoembryonic Antigen is Associated with Abdominal Visceral Fat Accumulation in Female Korean Nonsmokers. PloS one, 7, e43518.

https://doi.org/10.1371/journal.pone.0043518

[14] Yoshiike, N., Matsumura, Y., Zaman, M.M. and Yamaguchi, M. (1998) Descriptive Epidemiology of Body Mass Index in Japanese Adults in a Representative Sample from the National Nutrition Survey 1990-1994. International journal of Obesity and Related Metabolic Disorders, 22, 684-687. https://doi.org/10.1038/sj.ijo.0800651

Submit or recommend next manuscript to SCIRP and we will provide best service for you:

Accepting pre-submission inquiries through Email, Facebook, LinkedIn, Twitter, etc. A wide selection of journals (inclusive of 9 subjects, more than 200 journals) Providing 24-hour high-quality service User-friendly online submission system Fair and swift peer-review system Efficient typesetting and proofreading procedure Display of the result of downloads and visits, as well as the number of cited articles Maximum dissemination of your research work

Submit your manuscript at: http://papersubmission.scirp.org/

Or contact ss@scirp.org 